\title{
EMERGENCE OF WOMEN EMPOWERMENT THROUGH INCLUSIVE DEMOCRACY IN PAKISTAN
}

\author{
Ramzan Shahid ${ }^{1 *}$, Imran Ali ${ }^{2}$ and Sumaira Rehman ${ }^{1}$ \\ ${ }^{1}$ Department of Political Science and International Relations, University of Gujrat, Pakistan \\ ${ }^{2}$ Quaid e Azam University Islamabad Pakistan and English department, University of California Berkeley, USA
}

\begin{abstract}
Empowerment is "the result of the process which enables an individual to know about herself / himself, what she/he wants, express it, try to get it and fulfill their needs, enhance confidence, awareness, mobility, choices, control over resources and decision making power. The phenomenon of empowering someone implicitly comments on the powerlessness of the individual before. Empowerment is an active multidimensional process which should enable women to realize their identity and powers in all spheres of life, including greater autonomy in decision making as well as participation in all political activities". Politics being center of power is dominated by males in all over the world including Pakistan. The share of Women is nearly half of the population but still patriarchal society creates hurdles in their way of empowerment. Although all three constitution of Pakistan demonstrated for $5 \%$ quota of reserved seats for women in the Legislative Assembly, however, the demand for higher representation was always there. So due to this persistent demand of higher representation, the reserved quota was raised to $33 \%$ seats for women in legislative councils at the local, tehsil, municipality and district level and at the National and Provincial level it was enhanced to $17 \%$ making it highest representation in the world. In my article, I will unleash the struggle for women political representation and its impacts upon society.
\end{abstract}

Keywords: Women, empowerment, democracy, constitution

\section{Introduction}

Empowerment is defined as "a social action process that promotes participation of people, organizations, and communities in gaining control over their lives in their community and larger societies. With this perspective, empowerment is not characterized as an achieving power to dominate others, but rather power to act with others to effect change".(Jane Stein,1997)

Women's empowerment is a multifaceted and developing idea that is consistently being characterized recharacterized, explained, honed and illuminated. It has been related with the basic change of society through land and Labor reforms, opportunity to get education, self-governance and the privilege to access to property, the privilege to particular control over their bodies, sexuality and multiplication. It is a humble idea which can mean distinctive things in different perspectives. In this way it escapes a clear and brief definition. (Jane Stein, 1997)

Political Empowerment incorporates Women's portrayal on elected bodies. Political Empowerment is a way accepted to be the way to Women's uniformity, rights and satisfaction, while the instrumental view regards Women's political strengthening as the way to include in political issues, demonstrating enthusiasm for political process. Strengthening of Women monetarily guarantees strengthening in basic leadership inside a family unit; it can be contended that a similar power can be converted into interest in democratic governmental issues at the community level. 
Participating in the Political processes is the term that is much hard to clarify in light of the fact that it is utilized as a part of broad meaning. Participating in the Political process is an important way to Women's political speculation and strengthening in the basic leadership process or enhanced basic leadership control that will prompt women strengthening in the genuine feelings of the term of Women Empowerment. As it were, enhanced decision making power gives more chances to impact matters that influence our lives in the community and the general public at large scale. Women are kept away from the chances to partake in the decision making process. They are just latent spectators when the decisions are being made for their welfare. The challenge that is tremendously faced by ladies today is to expand their participation in the political circle that they may get position and hold the circumstances in the favor of them and end up dynamic part of decision making. While examining the structures of Society, we come to know that it is dissected on the basis of gender and not on the potential of individuals. With such an unfair division women become the most exploited group. (Jeffery,2002)

Discriminations based on gender orientation have turned out to be common framework in Pakistan. "Ladies' picture is as that of mother and spouse - the private and not public one ". (Burn, 1999) These roles which are culturally provided to women resist their way for empowerment. The roles generate thinking amongst the women about the myth that only external variables may provide them with the power and yet this isn't the situation as empowerment "isn't a commodity that can be given over to ladies". (Mittal, 2007)

For the purpose of women empowerment in their activism and being the part of political process would be the litmus to judge that how far it has been materialized. (Lucian W. Pye, 1958) So in this scenario the political situation in Pakistan is not a specific case and political ideologies are not specified. Most of the population in Pakistan thinks on the traditional patterns which eventually undermine the position of women among the masses regardless of assigning quotas at various level of representation in the political structures.

\section{Aim and Objectives of Study}

Following are the objectives of the study.

To highlight the importance of Women's role in the Politics of Pakistan

To analyze the enhanced role of Women in the legislation process after quota system in the Parliament

To find out the implications of reserved quota for Women in the parliament

\section{Research Methodology}

Qualitative technique will be used for the current study. The bulk of study will be taken through analysis of scholarly journals and papers, electronic journals, books and documents. Content analysis and textual interpretations will be used to develop findings. Analysis of the data taken by different books, reports, internet and articles is also provided. The main objective of the study is to know and evaluate the role of Women in political process in Pakistan. The data has been taken from different sectors of Political institutions and Elections Commission of Pakistan.

\section{Theoretical Framework}

Feminist Philosophy is most appropriate for the evaluation of current study as it is based upon the gender equality and equal rights including political rights which are meant as right to vote and right to contest election. Women empowerment has been considered in the viewpoint of gender based orientation noticed due to imbalance in the socio-cultural patterns of the society. But this is not the new phenomenon rather it acquired a 
portion of the social inheritance before partition of sub-continent. "Before 1947 '[women were] engaged in a struggle for self-realization and representation"”. (Cynthia Nelson and Shahnaz Rouse, 2000)

\section{Historical Background}

There were many educated ladies who believed in the active role of women in the politics before partition. The most notable figure behind the early struggle was Begum Shah Nawaz. She actively participated in different associations including the All India Women's Conference. She demanded for $10 \%$ reserved quota for women in the legislative assembly on the platform of Indian Association. Due to her struggle and strong voice 3\% quota for women was acknowledged in the act of 1935.(Sultana Samar,2008) She was also part of legislative assembly in 1946. (Shahnaz Rouse, 2006) Participating in the public matters created general awareness among the educated ladies about more extensive issues. After 1947, upper class Muslim ladies in Pakistan kept on supporting ladies' political strengthening through lawful changes. Both prominent ladies, Begum Shah Nawaz and Begum Shaista Ikramullah represented the women in the legislative body that was composed to make the first constitution of Pakistan. Their presence in the law making body assured in 1956 constitution, the rule of universal suffrage and reservation of special seats in the legislature for women. (Sabeeha Hafiz, 1981)Another organization for the political rights of women was APWA (All Pakistan Women Association)that was established by Begum Liaqat Ali Khan in 1949 and soon after this a number of different organizations sprang across the country. (Sabeeha Hafiz, 1981) Although most of these organizations couldn't become a platform for female demand of financial and political rights yet their presence was an asset in the political realms of country.

\section{Further Steps taken for the Empowerment of Women in Pakistan}

- The Gender Reforms Action Plan (GRAP) was introduced in 2002 that ended up in 2010. The purpose for starting the GRAP's was mainly the mainstreaming of gender based equity in all spheres of life, i.e., to make sure that all public private policies adopted should incorporate gender based equality amongst men and women.

- Another mile stone to enhance women empowerment in the country was signing of the "International Covenant on Civil and Political Rights (ICCPR)" in 2008. The purpose of said agreement was to guarantee free and fair elections under the Universal Declaration of Human Rights.

- There is an organization to monitor the elections system in Pakistan i.e. (Free and Fair Election Network, FAFEN) National Database and Registration Authority (NADRA)signed a MoU with FAFEN in February 2010. According to this agreement NADRA will ensure to update FAFEN about the low voter enlistment marking the specific zones. Upon the report from NADRA, FAFEN will take action by running a campaign of awareness among the general population in order to ensure $100 \%$ enrollment. It was decided to make joint efforts of NADRA-FAFEN panel to distinguish, among different issues, territories where registration for CNIC is low, particularly among females.

- From 1999 to 2008, it was further affirmed to reserve $10 \%$ quota for females in Central Superior Services and 5\% quota for ladies in all other public sector departments. Besides fixing the quota for women in different Government departments another innovativestep was taken, i.e.the quota for women in local governments was enhanced to $30 \%$ and at National 
and provincial level representation, it was increased to $17.5 \%$ under the Legal Framework

Order (LFO) 2002.

\section{Endeavors for Political Rights of Women in Pakistan}

Founder of Pakistan Quaid-i-Azam stated on $18^{\text {th }}$ April 1946, at the Muslim Convention in Delhi: "It is a matter of great happiness that Muslim women are also undergoing a revolutionary change. This change is of great importance. No nation in the world can progress until its women walk side by side with the men". (SairaBano, 2009)

Politics always remained a domain of power in the hands of males like-wise in Pakistan it is emphatically dominated by men. As per population indicators report of World Bank 2011, "females constitute $49 \%$ of the Pakistan's population, being unutilized in the national development because of their low expertise, low literacy rate and less empowerment in the domain of Politics". (Ali, 2012) Patriarchal setup of the society and social generalizations creates hindrances in the way of women empowerment. "The constitution of Pakistan considers all citizens equal before the Law and no discrimination is allowed in this regard. (Sachet, 2002); One case of how law attempts to guarantee the most extreme and equivalent support of female gender based orientation at political representation is apparent from the endeavors that are made "to enhance the representation of women in politics which are being ensured at remarkable level throughout the world". Reason for the allocation of quota is to overall increase the participation of women in all Government levels and to delimit their isolation in politics. (Ali, 2012)

In the first constitution of 1956, 3\% seats were reserved for women, which were raised to $5 \%$ in the 1973 constitution in both, national and provincial assemblies. This quota was further enhanced to $10 \%$ in 1984 just for the National Assembly that made it possible for twenty women to be indirectly elected for parliament.In any case, the reserve seats are allotted to the political parties on the basis of their voting proportion in the assembly and there is again an arrangement of assigning the names that are picked from the highest to lowest on a rundown of 60 ladies that each party presents to the election commission before elections. The constituent frame, at that point, is doubly undemocratic first in giving male overwhelmed political parties direct control over their candidates, and after that in giving male sole power to choose the female candidate. Women picked under such a framework hardly called in any genuine sense representative of the general population.

Female in Pakistan are clearly benefited from the quota. They have come across with the issues incorporating the absence of constituency because of the procedure of indirect elections. Thus they feel being helpless before the male councilors who choose them and mostly allot them the portfolio which only deal with "female issues". No doubt being half of the population, they are making their presence to be felt. As indicated by Farzana Bari " the fact that a huge number of women had taken active political role itself triggered social change, creating waves in the country's barnyards where traditional power structures still dominate the social and political lives of people"(Farzana Bari,2009).

\section{Reasons behind Low Participation}

In 1995, almost 50 years after the independence of Pakistan, the National Report for the Fourth UN World Conference for Women had to concede that women "continue to suffer in the face of oppressive patriarchal structures, rigid orthodox norms and stifling socio-cultural customs and traditions in Pakistan."(Sachet, 2002) If we look at the low participation of women in politics, we come across with three major reasons which include: purdah that is a religious obligation for a Muslim women, illiteracy and violence against women.(Kabir, 2003) Looking at demography and history of Pakistan, it is apparent that there are some factors that have prompted very little support for ladies in legislative issues. The variables which added to women's subordination incorporate "the social heritage; the-class based financial and political structure; the urban/rural partition; the 
patriarchal practices; and the part of religion in the polity". (Ali, 2012) Although keeping in mind the less number and low participation, females are always remained present in the politics of Pakistan and played an active role. Family obligations are a source of hindrance for women to take part in legislative issues. Females have the double duty of overseeing house and job at the same time. Masculinist, angry, estranging society is a reason behind low participation of ladies in Politics. (Lister, 1997)

\section{Institutional Barriers}

The key actors in the politics are always the Political Parties which can encourage or discourage the women to participate in the politics. Mostly these Political Parties are ruled by males from a privileged class, and this, together with sole control over administrative positions paved the way to discourage democratic practices added to obstructing women's entrance in governmental issues.

The institution responsible for continuation of democracy and conduct elections in the country is Elections Commission of Pakistan. It has immense gender lopsidedness in its workforce. It has kept on ignoring gender issues and problems faced by Women voters and candidates despite pressure from different female organizations in spite of technical support and urge from donor agencies. The ECP has failed to keep up sexual orientation disaggregated data of voters' turnout, take measures to bridge the gap in electoral rolls, or launch some awareness campaigns to increase the voter turnout. It lagged to take a move against those where female were banished from voting, or react insufficiently to occurrences of viciousness against women voters, candidates or poling agents during elections.

In spite of the fact that more female are currently contesting in elections for general seats, women portrayal in the national and provincial assemblies and in the senate are basically accomplished through a quota that is filled through indirect way of nomination. As these females are elected indirectly so they don't have powers base since they are not answerable to any constituency, which strengthens their reliance on the Party leadership. What's more, however women chosen through quota system on reserved seats have played a key role in legislation for women and featuring human rights issues, they are for the most part thought to be less vital in contrast with their colleagues directly elected on general seats. The Code of Conduct for General Elections 1997 also prohibits political parties, candidates who are participating in elections and political workers to proliferate against female participation.

\section{Socio-Political Barriers}

Ladies are barred from the decision-making in family matters. Same is the situation with the Nation's political framework. They are not allowed to make decisions all alone. Low social, financial and political interest in building women's human capital characterizes female own particular perception and the perception of political issues. Ladies often need training, money, knowledge, learning, aspiration and political abilities to go into politics. These individual and mental variables undermine women's ability to partake in administrative structures, and together with ladies' familial obligations leave little time and space for them to go into politics.

Being Female candidate brings several hindrances starting from the absence of party backing to financial limitations. Ladies are denied party tickets on the supplication that they need socialization and finance, and are required to run their election campaign from their own assets, just like the men. The mindset of administration in the political parties for the most part reflects patriarchal demeanors that are present in the private circle of the home. Aggressive electioneering campaigns and savagery and in addition fear of provocation, misconduct and abuse of character are to a great degree debilitating components for ladies, especially without satisfactory security arrangements. Since independence, Pakistan has faced severe violence in political sphere. Very famous female politicians have lost their lives in this cycle of savagery, including former Prime Minister Benazir Bhutto 
and a former minister and an activist Ms. Zille HumaUsman. Both were killed in the presence of general public around them.

\section{The way Forward}

- The government might likewise guarantee that ladies parliamentarians, particularly those on reserved seats, do get their due share of funds as they ought not to be denied just in light of the fact that they are not directly elected.

- Election Commission of Pakistan must request each political party to engage ladies and enhance their part and share in the decision-making bodies.

- Each political party must guarantee the incorporation, in their brochures, of projects started for women development. They ought to likewise raise issues to protect females from domestic and social violence.

\section{Conclusion}

The approach to empowerment is incomplete without empowering female politically and giving them equal participation in the efforts to run the country. It is extremely remarkable for ladies to contend for their empowerment in order to be the part of decision making process in politics and lawmaking bodies. There are no restrictions on women to take part politics in the constitution of Pakistan. They have quota of reserved seats of $33 \%$ at union council, Tehsil and District level as well as $17 \%$ at National, Provincial assemblies and Senate. However, their importance in the political parties and in the political structure at the local, provincial and national level remains inadequate because of religious, social and structural barriers.

\section{References}

Jane Stein, (1997). Empowerment and Women's Health: Theory, Methods and Practice, Zed Books, London.

Weeks, Jeffery, "Power and the State," in An Introduction to Women's Studies, ed. InderpalGrewaland CarenKaplan, (New York: McGraw Hill, 2002), 187.

Bari, Farzana, Role and Performance Assessment of Pakistani Women Parliamentarians 2002-07, (Islamabad: Pattan, 2009), 2.

Burn, Shawn Meghan, Women Across Cultures - A Global Perspective. (Mayfield: Mountain View, 1999), 197.

Mittal, Rakhi, "Women's Equality: Still a Dream," in Women Empowerment Today's Vision for Tomorrow's Mission, ed. MeenuAgarwal, (News Delhi: Mahamaya Publishing House, 2007), 173.

Adriana Craciun, (2002). Mary Wollstonecraft's A Vindication of the Rights of Woman, Ch-2, Rout ledge, London.

Lucian W. Pye, (1958). The Non-Western Political Process, The Journal of Politics, 20(3), 471.

Cynthia Nelson and Shahnaz Rouse,(2000). Situating Globalization: Views from Egypt,

Bielefeld, Transcript Verlag.

Sabeeha Hafiz, (1981). The Metropolitan Women in Pakistan: Studies, Royal Book Company, Karachi.

SairaBano, (2009). Women in Parliament in Pakistan: Problems and Potential Solutions, Women's Studies Journal, 23(1), 19-35.

Ali, AzraAsghar\&Akhtar, M.Javaid, "Empowerment and Political Mobilization of Women in Pakistan: A Descriptive Discourse of Perspectives," Pakistan Journal of Social Sciences (PJSS), Vol. 32, No. 1 (2012):.221228.

Sachet, Legal Empowerment of women in Pakistan, Volume 1, Issue 3 (Special), (2002) accessed July 5, 2014 on http://www.sachet.org.pk

Sachet, Legal Empowerment of women in Pakistan, Volume 1, Issue 3 (Special), (2002) accessed July 5, 2014 on http://www.sachet.org.pk 
Lewis, Jone Johnson. "International Woman Suffrage Timeline-Winning the Vote for Women Around the World". Accessed on September 12, 2014 on

http://womenshistory.about.com/od/suffrage/a/intl_timeline.htm

“A history of woman suffrage around the world".Encyclopedia Britannica, Inc. Accessed on September 9, 2014 on http://search.eb.com/women/article-9077370

Kamal, Mustafa."Women and Voting in Pakistan". (2012)Accessed on

September 10, 2014 on lubpak.com/archives/229403

Kabir, Farah, Political Participation of Women in South Asia, 2003, accessed on July 5, 2014 on http://www.onlinewomeninpolitics.org/south/2003_wip_sa.doc.

Lister, Ruth, Citizenship: Feminist Perspectives, (New York: New York University Press, 1997).

FareedaShaheed and KhawarMumtaz, Two Steps Forward One Step Back, p.119.

News, December, 22. 2002.

Dawn, May, 132005.

News, August, 242005. 